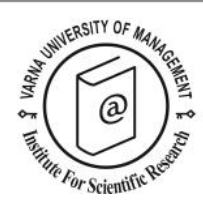

\title{
Scientific output of the European Journal of Tourism Research: A bibliometric overview and visualization
}

\author{
Mohammad Soliman ${ }^{1 *}$, Oleksii Lyulyov², Hanna Shvindina ${ }^{3}$, \\ Ronnie Figueiredo ${ }^{4}$ and Tetyana Pimonenko ${ }^{5}$
}

\footnotetext{
${ }^{1}$ University of Technology and Applied Sciences, Salalah CAS, Oman; Faculty of Tourism \& Hotels, Fayoum University, Egypt. Email: msoliman.sal@cas.edu.om

${ }^{2}$ Head of Department of Marketing, Sumy State University, Ukraine. Email: alex_lyulev@econ.sumdu.edu.ua

3 Head of the Department of Management, Sumy State University, Ukraine; Fulbright Alumna, USA.

Email: shvindina@management.sumdu.edu.ua

4 NECE, Research Center in Business Sciences, University of Beira Interior - UBI. Business \& Law Unit, School of Business, Universidade Europeia - UE, Portugal. Email: ronnie.figueiredo@universidadeeuropeia.pt

5 Department of Marketing, Sumy State University, Ukraine; Fulbright Alumna, USA. Email: tetyana pimonenko@econ.sumdu.edu.ua

* Corresponding author
}

\begin{abstract}
This paper aims to analyse and visualise the scientific output of the European Journal of Tourism Research (EJTR) by employing a set of bibliometric metrics; including productive and impact measures, co-authorship analysis, cocitation analysis, and co-occurrence analysis. The collected and analysed data involved 304 peer-reviewed articles published in the EJTR during the period from 2008 to 2020 within Scopus database. The results indicated that there is a substantial growing trend and evolution in publications and ranking of the EJTR during the given period. Additionally, a number of leading institutions and countries significantly contributed to the EJTR. Moreover, some top-tier academic journals and authors cited the articles published by the EJTR. Furthermore, the co-occurrence analysis identified seven clusters of research areas among the EJTR published papers over the selected period. Theoretical and practical contributions are presented as well as limitations and further research avenues are outlined.
\end{abstract}

Keywords: Bibliometrics; Visualisation; Peer-reviewed articles; Scopus database; European Journal of Tourism Research

Citation: Soliman, M., Lyulyov, O., Shvindina, H., Figueiredo, R. and Pimonenko, T. (2021). Scientific output of the European Journal of Tourism Research: A bibliometric overview and visualization. European Journal of Tourism Research 28, 2801

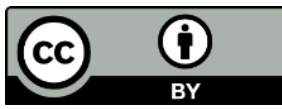




\section{Introduction}

Over the past decades, there have been significant growth and evolution in studies within the field of tourism and hospitality, which has become the focus of academic scholars' interests around the world. Research in this field is dating back to more than 50 years and refers to more than 100 existing journals. With regard to the evolution of tourism journals, 'Journal of Travel Research' was founded in 1968, 'Annals of Tourism Research' appeared in 1973, and 'Journal of Hospitality \& Tourism Research' and 'Tourism Recreation Research' dated back to 1976. One of the reasons for the small number of journals in the $1970^{\text {th }}$ is that tourism research was not being as widely considered or accepted as it should be. Secondly, tourism was not perceived as a major discipline but a subject highly suitable for academic study by researchers from several disciplines (Butler, 2015).

The scale and forms of tourism have changed with time, and consequently, the number of academic journals in the field increased. In 1982, 'Tourism Management' was established, and later, in 1989, the first volume of 'International Journal of Contemporary Hospitality Management' was published. Currently, there are 132 Scopus-indexed journals under the subject area of 'Tourism, Leisure and Hospitality Management' (Scopus database, 2020). According to the Scimago Journal \& Country Rank (SJR, 2020), 123 academic journals exist within this category. Due to the increasing number of publications within tourism and hospitably context, some bibliometric studies were conducted for the scientific production of tourism and hospitality academic journals.

The current paper mainly focuses on the 'European Journal of Tourism Research' (EJTR) that is a leading tourism journal in Europe and is considered one of the promising journals within the tourism and hospitality field all over the world. The EJTR is an open-access academic journal that publishes papers related to tourism management, tourism marketing, tourism sociology, psychology in tourism, tourism geography, political sciences in tourism, findings in tourism-related applied science, and cultural heritage and national identity affecting travel and tourism marketing (The EJTR Website, 2020). The EJTR was founded in 2006, and the first issue appeared in February 2008. The publisher is Varna University of Management in Bulgaria. The EJTR was accepted in Scopus in 2011, and all its issues starting from 2008 have been indexed in Scopus database. It is the highest-ranked journal published in Bulgaria in the field of 'Social Sciences' and one of the most productive journals within the tourism and hospitality area, especially in Europe (Scopus database, 2020). According to the SJR (2020), the EJTR has the $74^{\text {th }}$ position in the SJR ranking globally, the second position in Europe, and the first position in Bulgaria.

Considering the leading role of the EJTR, and its evolution, along with an increasing number of publications over the last 12 years, the aim of this study is to conduct bibliometric analysis for the scientific outcome of the EJTR by using a wide range of bibliometric indicators with their visualisation via VOSviewer software (Van Eck \& Waltman, 2018). To be more specific, this paper employed two methods of evaluative bibliometrics, which are productivity and impact metrics, to give a precise insight into the overall trends and performance of the EJTR in terms of scholarly publications. In addition, three relational bibliometric approaches (i.e., co-authorship analysis, co-citation analysis, and co-occurrence analysis) were applied to visually map and outline the contents, directions and themes of collected data associated with peer-reviewed articles published in the EJTR between 2008 and 2020.

The contribution of this article is to provide clear insights on the evolution and main trends of the scientific outcomes of the EJTR and to reveal the most significant contributors and most-cited authors of published articles. In addition, the co-citation analysis revealed the tendency in citations between the EJTR and top-ranked journals in the domain that may influence the ranking of EJTR, and further 
strategy of publishing. Moreover, the clusters for topics and keywords may be used for re-thinking the scale and scope of the journal, and to attract more promising authors and topics. Broader speaking, the results of this current study may become a beacon for scholars in the tourism and hospitality field in terms of verification of urgency of a topic or research questions.

The rest of this paper will be structured as follows. In Section 2, we provide a review of the literature concerning the study subject. Section 3 includes research methods, whereas Section 4 illustrates the study findings and results. Discussion and implications are given in Section 5. Lastly, limitations and directions for further research are provided in Section 6.

\section{Literature review}

Bibliometric research overview

Over the recent years, many studies linked to the bibliometric approach were conducted, as its toolbox allows analysing any research area, identifying the leading trends, most influential authors, and seminal works. The bibliometric research may prove the interconnections between several fields of research and may justify a new flow of academic thoughts. The vivid example is the work of Fahimnia, Sarkis, and Davarzani (2015), who proved that green supply chain management is a separate direction in research and offered the roadmap for further investigation in this field. The term 'bibliometrics' is referred to Pritchard (1969), who introduced it originally, but the recent findings in the field showed expansion of bibliometrics in many different fields, including management studies (Mas-Tur, Kraus, Brandtner, Ewert, \& Kürsten, 2020), measuring performance in health (Marsh, 2020), affective computing (Guo, Li, Lv, Liu, \& Duffy, 2020), etc. Furthermore, bibliometrics can be used for the identification of emerging trends, such as multidisciplinary research on coopetition (Shvindina, 2019), or to find an unrevealed knowledge gap in sciences (Tomaszewski, 2019) by using cluster analysis provided among different bibliometric software. Bibliometric studies also give a lot of insights about publication strategy for the next generation of scholars (Mulet-Forteza, Martorell-Cunill, Merigó, Genovart-Balaguer, \& MauleonMendez, 2018; Zopiatis, Theocharous, \& Constanti, 2015). Additionally, various bibliometric studies are related to tourism such as thermalism, thalassotherapy, and spa (del Río-Rama, Maldonado-Erazo, \& Álvarez-García, 2018), strategic management-related research (Koseoglu, Law, \& Dogan, 2018; Köseoglu, Law, Okumus, Barca, \& Dogan, 2019), co-creation in tourism (Tregua, D'Auria, \& Costin, 2020), etc.

\section{Bibliometric studies in tourism}

More scholars got involved in the investigation of tourism development, tourism management and marketing, tourism behavior, tourism-related activities, etc., consequently, tourism research is published regularly in a large number of refereed academic journals. Thus, the number of tourism and hospitality publications tremendously increased, including bibliometric studies.

In this regard, we demonstrate briefly examples of bibliometric studies that were conducted to map a certain topic/matter within the tourism context. One of the earliest papers in bibliometric analysis in the field of hospitality and tourism was performed by McKercher (2012) where scholars offered an alternative way to measure the influence of the publication in a field. "Influence ratio" is offered to measure as "a share of citations generated by a journal with the share of papers published by that journal" that allows identifying the most influential journal among others. The study of Turkish tourism and hospitality literature was developed by Evren and Kozak (2014) for the period between 2000 and 2010. The trends of citations and the scientific performance of institutions were examined, as well as research quality of papers. The growing number of new research papers, and new areas of research and development of Turkish tourism literature in general were revealed. This was explained by the change in quality of research towards empiric studies dominance. 
The study of Zopiatis et al. (2015) defined the changes in the publishing strategies, such as a shift from one-contributor strategy to cooperation between two and more authors, which boosted the development of the field. Among other factors of further development and interdisciplinary expansion of this research field the launch of numerous hospitality and tourism doctorate programs was named. The unique combination of multiple correspondence analysis (MCA), clustering and variables factor map (PCA) distinguished this paper among others, and yet the authors raise the concern about the controversiality of confrontation "ranking" versus "context of a paper". Additionally, an object for the bibliometric analysis can be as much as wide as well as narrow according to formulating a research question. Therefore, bibliometric analysis for every particular question, namely using social media in the tourism sector was accomplished in 2017 by Leung, Sun, and Bai (2017).

Other bibliometric work (Shen et al., 2018) that aimed to create a universal classification of published papers in the tourism and hospitality field with special focus on the geographic location, which allowed to reveal country co-occurrence relationships and to generate the spatial distribution map of focus countries globally and in different regions. The remarkableness of this research is the broader scope of research that included 32 journals. Later, Benckendorff and Shu (2019) applied bibliometric methods to measure the contributions and influence of scholars in the tourism and hospitality field, using Google Scholar profile h-index and g-index. This research boomed a new cycle of debates in the field.

Remarkable research on contributions in the tourism, leisure, and hospitality fields over the 40 years was accomplished by Mulet-Forteza, Genovart-Balaguer, Mauleon-Mendez, and Merigó (2019) who provided a detailed overview of the most influential papers, authors, contributors by affiliation (institutions and countries) based on the Web of Sciences (WoS) dataset. One more exceptional study (Merigó, Mulet-Forteza, Martorell, \& Merigó-Lindahl, 2020), structuring of the most influential papers in tourism, leisure and hospitality research using the WoS database, revealed the recent trends in the field and gave insights for the future directions in the next years.

\section{Bibliometric analysis of tourism and hospitality journals}

With the increasing number of publications in tourism academic journals, a number of bibliometric studies were conducted to review, analyse and map the scientific production of these journals (e.g., the Journal of Sustainable Tourism, Journal of Travel \& Tourism Marketing, International Journal of Hospitality Management, International Journal of Contemporary Hospitality Management, Journal of Heritage Tourism, Anatolia, etc.).

To begin with, the paper devoted to the Journal of Sustainable Tourism (Mauleon-Mendez, GenovartBalaguer, Merigo, \& Mulet-Forteza, 2018) represented a broad set of bibliometric tools, including the productivity of the journal (number of papers) and its influence (number citations), a graphical mapping of the bibliographic data via VOSviewer, namely co-citation of journals in the Journal of Sustainable Tourism, a bibliographic coupling of countries representatives published, etc. The findings proved the growing concern for sustainable development in tourism and hospitality.

Publication, citation structure, and network analysis were done for the Journal of Travel \& Tourism Marketing (Mulet-Forteza et al., 2018). The visualisation of similarities between other journals revealed the patterns in co-citations between journals; notably, there are three nodes: journals in the tourism, leisure, and hospitality management field, marketing field, and leisure field.

The study for the International Journal of Hospitality Management (Cunill, Salvá, Gonzalez, \& MuletForteza, 2019) has the same logic: the bibliometric analysis of main contributions, co-citation analysis 
by authors, universities, countries and journals, bibliographic coupling by countries, and co-occurrence of keywords in papers.

The bibliometric study conducted for the production of the International Journal of Contemporary Hospitality Management (Mulet-Forteza, Genovart-Balaguer, Merigó, \& Mauleon-Mendez, 2019) has used a comprehensive set of methods to represent the bibliographic data, among them: the number of publications, number of citations, ratio citations per paper, h-index, citation thresholds method, most productive authors, institutions, and countries; a number of downloads of published papers; the most influential subjects; and the number of publications and citations per person. Besides the journal's significant evolution, this study foresees the hot topics in the field that may become very promising for future research.

The study of Kumar, Sureka, and Vashishtha (2020) was performed for the Journal of Heritage Tourism in the period from 2006 to 2019. It was designed using a combination of such bibliometric indicators such as number of publications and citations, h-index, the tanking of the contributing authors, institutions and countries, papers, as well as keywords co-occurrence mapping via VOSviewe, and Gephi software to present the results graphically. The most seminal works were revealed, and the most popular topics, along with potential trends that have not received attention yet but may become the foci for the special issues in the future.

The research for Anatolia (Mokhtari, Soltani-Nejad, Mirezati, \& Saberi, 2020) gathered bibliometric and altmetric study based on both Scopus database and Anatolia database to avoid the limitations of the previous studies. It is essential to analyse all the journal's papers, including those that were published before the journal got indexed in Scopus database. The combination of methods and software tools (VOSviewer, Excel) resulted in altmetric score for the most cited papers (to find the impact in social media), the ranking of the most productive authors, most highly productive countries and regions, contributing institutes and universities, mapping of the keyword co-occurrence of the journal, cocitation network of journals and authors cited by Anatolia. As a result, the potential gaps were revealed in the journal in comparison with other related journals, which is the orientation for further development of the journal.

The journals' productivity and influence may be analysed in a set of several journals for better comprehensive benchmarking related to the region, as it was performed by Moreno-Gil, Parra-López, Picazo-Peral, \& Díaz-Domínguez (2020). The productivity of the journals, institutions, authors, and coauthorship reallocation were investigated, but co-citation mapping and keywords co-occurrence have remained outside the research. It proves that concentration on one journal production has certain advantages, which will be mentioned further.

With regard to the EJTR, there are few previous findings on relevant bibliometric analysis. One of them is the research of Chang \& McAleer (2012) that revealed the high ranking of the EJTR (by h-index, citation performance per paper online, research assessment measures) among other journals in the area. Moreover, the study of Ivanov (2018) presented the journal's full history, its evolution, the trends of submissions and co-citations, and key performance indexes of the journal.

However, it should be mentioned that the scientific productions of the EJTR haven't been analysed thoroughly by using a blend of bibliometric tools to reveal the trends in publications, ranking, most contributing authors, institutions and countries, co-citations, co-authorship analysis, co-occurrence analysis, and future research tendencies using clustering techniques and mapping. The trends of 
development, the efficiency of publishing strategy can be measured and explained with proper visualisation, and therefore, the methodology of bibliometric research was developed and performed in the current study for that specific journal. That is, the current paper aimed to conduct a solid and comprehensive bibliometric analysis of the EJTR from its establishment to the date of research.

\section{Research methods}

Depending on Scopus database, the data related to the scientific production of the EJTR were collected by the end of September 2020. To this end, 365 documents were recorded through database searching as follows: 304 peer-reviewed articles; 43 notes; 11 editorials; and 7 review books. To filter the data, we have selected and focused on the published papers, and then eliminated the other types of publications (i.e., notes, editorials, and reviews). As a result, the gathered and analysed data involved 304 articles published in the EJTR from 2008 to the end of September 2020.

As previously mentioned, this paper employed a bibliometric approach to analyse and visually map the articles published in the EJTR during the given period. According to Benckendorff and Zehrer (2013), and Koseoglu, Rahimi, Okumus, and Liu (2016), there are three main methods of bibliometric analysis, namely review studies; evaluative techniques; and relational techniques. In this study, we have employed two bibliometric methods, which are evaluative metrics and relational metrics.

Firstly, according to Hall (2011), evaluative methods include three types of measures: productivity metrics, influence metrics, and hybrid metrics. In the current paper, the productive and impact measures were employed to present a clear picture of the main trends and performance of the EJTR. More specifically, with regard to the productive measures, we used a number of indicators (e.g., the annual production of the EJTR, number of cited articles, the most productive authors, the most productive institutes and countries contributed to the EJTR).

Concerning the impact measures, we depended on some metrics, including the annual citation, the total number of citations, and the number of citations by journal and scholar. Secondly, relational methods were employed in this paper by using a set of metrics involving co-authorship analysis, cocitation analysis, and co-occurrence analysis to visually analyse the major contents and relationships between the collected data in terms of research collaboration and key themes. In this regard, there are many previous studies (del Río-Rama, Maldonado-Erazo, Durán-Sánchez, \& Álvarez-García, 2019; del Río-Rama et al., 2018; Padrón-Ávila \& Hernández-Martín, 2020) that conducted evaluative and relational bibliometric methods within the tourism and hospitality context.

With respect to the data analysis process, the collected data were organized and filtered in an Excel sheet. Next, we used Microsoft Excel to do a set of analyses related to the productive and impacts measure (e.g., the annual production of the EJTR; The most prolific institutions, countries and authors in the EJTR; and the most cited articles). In addition, VOSviewer software was used, as it is proven to be an effective tool for keywords and themes visualization that enables generating and identifying the interconnections between main terms in a field of research. More particularly, VOSviewer was employed to perform analyses associated with the relational metrics (i.e., co-authorship analysis, cocitation analysis and co-occurrence) of the EJTR's scientific outcomes. 


\section{Findings}

Annual publication of the EJTR

According to Ivanov (2018), submissions to the EJTR have been started in 2007, including 22 articles and 2 book reviews. Regarding articles, out of 22 submitted papers, 6 papers were accepted for the first publication in the EJTR that appeared in 2008.

Figure 1 points out the yearly scientific production of the EJTR in terms of peer-reviewed articles during the period between 2008 and 2020. Overall, publications in the EJTR recorded a considerable growing trend over the given period, particularly in recent years. Increasing from 7 articles in 2008 to 21 papers in 2012, the number of articles then reached a peak of 41 in 2017. This was followed by a period of decline, with a number of papers plunged to 26 in 2018, then it increased to 35 and 36 papers in 2019 and 2020 respectively. A key point should be considered here is that the last date of searching for the EJTR's articles on Scopus database was September $30^{\text {th }}, 2020$. Consequently, it is predicted that the number of published articles in the EJTR will increase by the end of 2020.

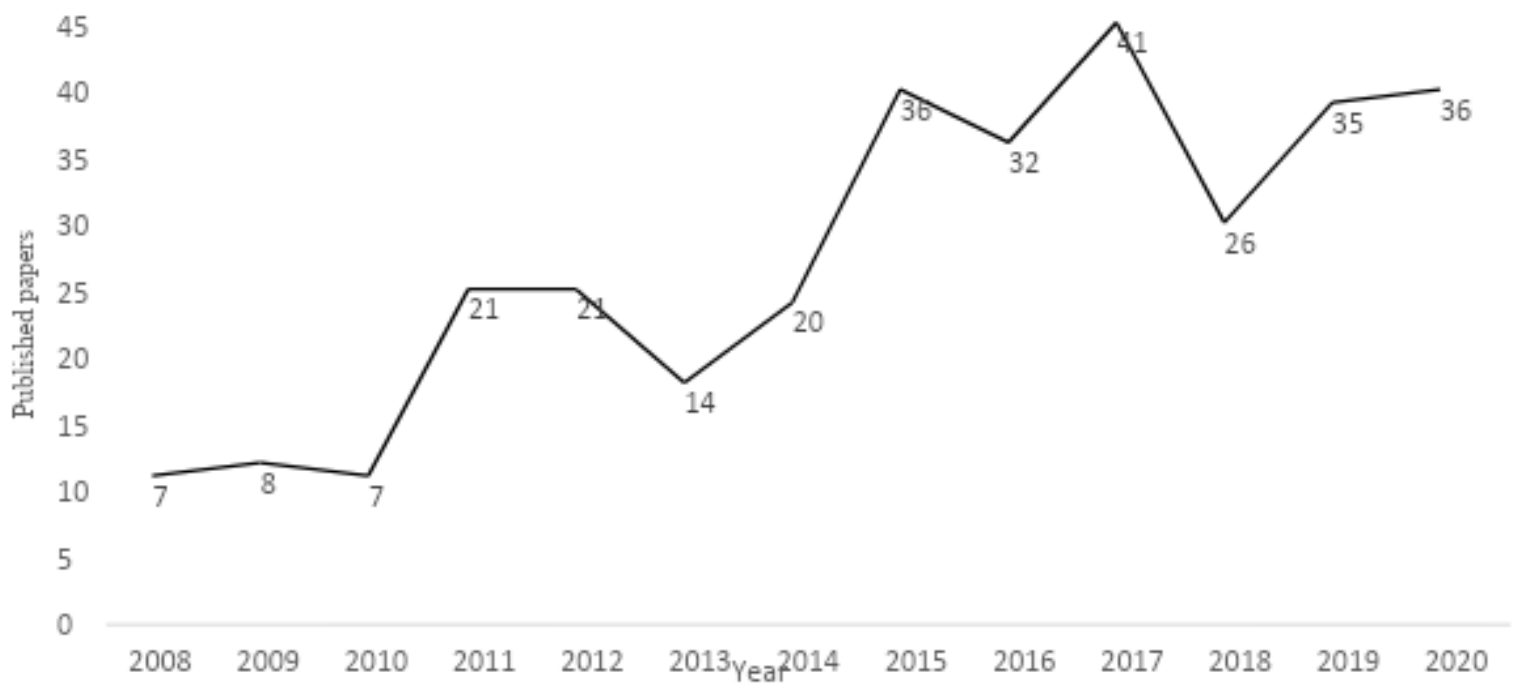

Figure 1. Distribution of published articles in the EJTR by year (2008-2020)

\section{Ranking of the EJTR}

The journal ranking is crucial for some scholars all over the world, as they are required to publish in database indexed journals for their career vacancies and/or promotion purposes. In this regard, it should be considered that, based on Scopus database, the EJTR is classified under two subject areas with their related categories: Social Sciences (Geography, Planning and Development) and Business, Management and Accounting (Tourism, Leisure and Hospitality Management). Table 1 depicts the ranking of the EJTR according to CiteScore and SJR within the aforementioned categories. Overall, it is evident that the rank of the EJTR, within both CiteScore and SJR rank, was increased over the given period. Interestingly, the rank of the journal within the category of 'Geography, Planning and Development' is slightly greater than its rank within the category of 'Tourism, Leisure and Hospitality Management'. 
Table 1. Ranking of the EJTR according to CiteScore and SJR rank

\begin{tabular}{|c|c|c|c|c|c|c|c|c|c|c|}
\hline \multirow{3}{*}{ Year } & \multicolumn{7}{|c|}{ CS Rank } & \multicolumn{3}{|c|}{ SJR Rank } \\
\hline & \multirow[t]{2}{*}{$C S$} & \multicolumn{3}{|c|}{${ }^{*} G P D$} & \multicolumn{3}{|c|}{${ }^{*} T L H M$} & SJR & \multirow{2}{*}{$\frac{{ }^{*} G P D}{Q}$} & \multirow{2}{*}{$\begin{array}{c}{ }^{*} T L H M \\
Q \\
\end{array}$} \\
\hline & & $R$ & $\%$ & $Q$ & $R$ & $\%$ & $Q$ & & & \\
\hline 2008 & - & - & - & - & - & - & - & - & - & - \\
\hline 2009 & - & - & - & - & - & - & - & 0.178 & 3 & 4 \\
\hline 2010 & - & - & - & - & - & - & - & 0.167 & 3 & 4 \\
\hline 2011 & 0.3 & $\#_{361 / 507}$ & $28^{t h}$ & 3 & $\# 61 / 68$ & $11^{\text {th }}$ & 4 & 0.199 & 3 & 4 \\
\hline 2012 & 0.4 & $\# 380 / 540$ & $29^{t h}$ & 3 & \#67/75 & $11^{\text {th }}$ & 4 & 0.348 & 2 & 3 \\
\hline 2013 & 0.7 & $\# 310 / 561$ & $44^{\text {th }}$ & 3 & \#6o/81 & $26^{t h}$ & 3 & 0.356 & 2 & 3 \\
\hline 2014 & 0.6 & \#379/572 & $33^{r d}$ & 3 & \#69/82 & $16^{\text {th }}$ & 4 & 0.247 & 3 & 4 \\
\hline 2015 & 0.5 & $\# 425 / 584$ & $27^{\text {th }}$ & 3 & $\# 74 / 82$ & $10^{t h}$ & 4 & 0.158 & 3 & 4 \\
\hline 2016 & 0.7 & \#394/606 & $35^{\text {th }}$ & 3 & $\# 71 / 89$ & $20^{t h}$ & 4 & 0.242 & 3 & 4 \\
\hline 2017 & 1.0 & \#350/627 & $44^{\text {th }}$ & 3 & \#66/10o & $34^{\text {th }}$ & 3 & 0.262 & 3 & 4 \\
\hline 2018 & 1.6 & $\# 279 / 656$ & $57^{\text {th }}$ & 2 & \#58/113 & $49^{\text {th }}$ & 3 & 0.413 & 2 & 3 \\
\hline 2019 & 1.7 & $\# 276 / 679$ & $59^{t h}$ & 2 & \#62/119 & $48^{\text {th }}$ & 3 & 0.308 & 3 & 3 \\
\hline
\end{tabular}

Note: CS= CiteScore; SJR= Scimago Journal Rank; ${ }^{*}=$ Scopus category; GPD= Geography, Planning and Development; TLHM= Tourism, Leisure and Hospitality Management; $R=$ Rank; \%= Percentile; $Q=$ Quartile. Source (Scopus database, 2020; SJR, 2020)

Affiliation and country analysis

Table 2 reveals the most productive institutes and countries that contributed to the EJTR between 2008 and 2020. With regard to the most prolific institutions, the results indicate that both Universidade de Aveiro (Portugal) and Università degli Studi di Sassari (Italy) have the highest figures of published articles (8 papers for each one) in the EJTR from 2008 to 2020.

Concerning the highly productive countries, it is revealed that the peak value is recorded amongst Spain (55 articles). This is followed by Portugal, Italy and the United States with 27, 25 and 23 papers respectively. The rest of the countries, mentioned in Table 2, have articles lower than 20 over the period given from 2008 to 2020 .

Table 2. The most prolific institutions and countries in the EJTR (2008-2020)

\begin{tabular}{llll}
\hline Institutes & $\begin{array}{l}\text { No. of } \\
\text { articles }\end{array}$ & Country & $\begin{array}{l}\text { No. of } \\
\text { articles }\end{array}$ \\
\hline Universidade de Aveiro, Portugal & 8 & Spain & 55 \\
Università degli Studi di Sassari, Italy & 8 & Portugal & 27 \\
UiT The Arctic University of Norway, Norway & 7 & Italy & 25 \\
Universidad de Las Palmas de Gran Canaria, Spain & 6 & United States & 23 \\
Universidad de Huelva, Spain & 6 & Turkey & 19 \\
University of Johannesburg, South Africa & 5 & United Kingdom & 17 \\
Universitat de Girona, Spain & 5 & Australia & 11 \\
Universidade de Coimbra, Portugal & 5 & South Africa & 11 \\
Instituto Politcnico de Coimbra, Portugal & 5 & Croatia & 10 \\
North-West University, South Africa & 5 & Germany & 10 \\
Università degli Studi di Cagliari, Italy & 5 & Malaysia & 10 \\
& & Norway & 10 \\
\hline
\end{tabular}


Co-authorship analysis

The findings showed the most prolific authors who have published papers in the EJTR from 2008 to 2020 are: Giacomo Del Chiappa (5 articles); Juan Gabriel Brida; James Hanrahan; Ricardo Melo; Bình Nghiêm-Phú; Harald Pechlaner; Melville Saayman; Hugo Skaalsvik; and Suosheng Wang (4 articles).

The results of co-authorship analysis showed that Giacomo Del Chiappa is the leader in publication in the EJTR over the given period. Giacomo Del Chiappa with her co-authors (Carlota Lorenzo-Romero, Martina González Gonzales Gallarza, Marcello Atzeni, Salvatore Loriga, Jessica Mei Pung, Marcello Risitano, Stefano Dall'Aglio, Salvatore Loriga, and Marta Meleddu) published 5 articles in the EJTR. Juan Gabriel Brida with his co-authors (Wiston Andrian Risso, Edgar J. Sánchez Carrera, Elvio Accinelli, Marta Meleddu, Manuela Pulina, and Statzu Vania), Melville Saayman with co-authors (Andrea Giampiccoli, Andrea Saayman, Engelina Du Plessis); Bình Nghiêm-Phú with co-author (Awangku Hassanal Bahar Pengiran Bagul); Wang S. with co-authors (Amanda Kay Cecil, Yaoyi Fu, and Sotiris H. Avgoustis); Harald Pechlaner with co-authors (Bachinger Monika, Volgger Michael, and AnzengruberFischer Elisabeth); James Hanrahan (Domhnall Melly, Emmet McLoughlin, Ann Marie Duddy, and Séan Duffy); Ricardo Melo with co-authors (Claude Sobry, Ana Lúcia Falcão, António Sérgio Damásio, Ana Cristina Portugal, Francisco Ascenso, Francisco Ascenso Campos, and Fernando Manuel Lourenço Martins); and Hugo Skaalsvik with Jon Arild Johannessen had 4 publications.

The five clusters of the scholars could be allocated based on the results of the co-authorship analysis (Figure 2). Each cluster had its own scientific leader who had published the highest number of papers in the EJTR. The green cluster combined the co-authors of Giacomo Del Chiappa (Carlota LorenzoRomero, Martina González Gonzales Gallarza, Stefano Dall'Aglio, Marcello Atzeni, Jessica Mei Pung, Marcello Risitano, Salvatore Loriga,. and Marta Meleddu). The red cluster involves the main co-authors of Juan Gabriel Brid (Marta Meleddu, Manuela Pulina, Statzu Vania, Wiston Andrian Risso, Edgar J. Sánchez Carrera, and Elvio Accinelli).

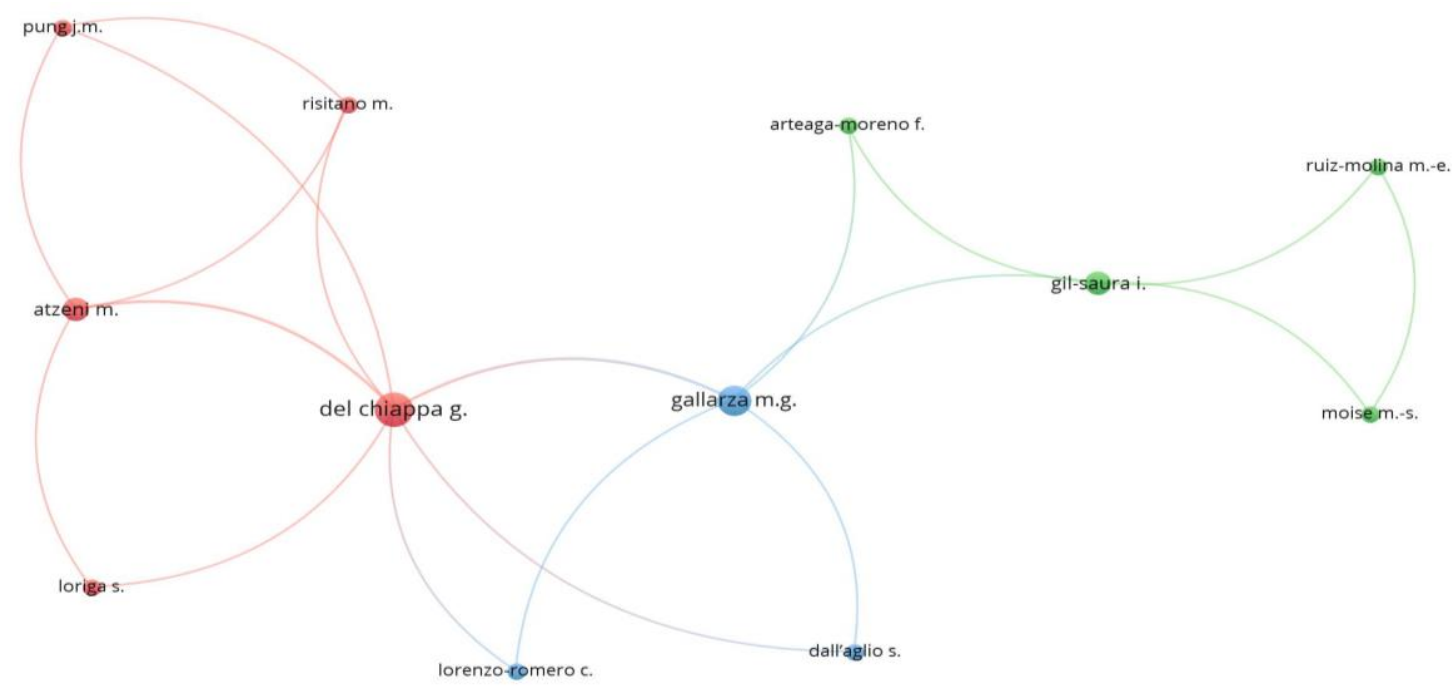

Figure 2. Results of the co-authorship analysis 
Citation and co-citation analysis

Figure 3 shows the results of the analysis of total citations. It is evident that the number of EJTR's citations has been increasing during recent years. There are 132 and 163 citations in 2016 and 2017 accordingly, 245 citations in 2018 and 276 citations in 2019

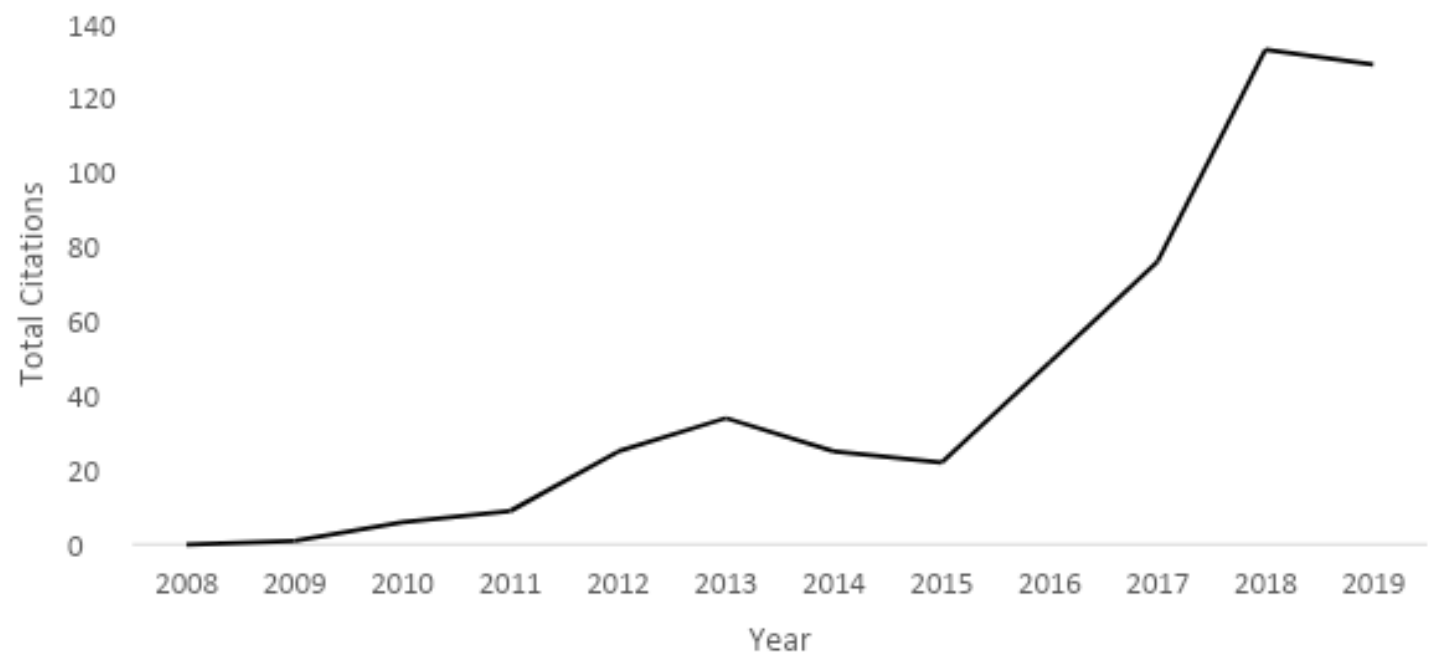

Figure 3. Total citations received by the EJTR by year (2008-2019)

Table 3 depicts the highly cited articles published in the EJTR from 2008 to 2020 according to Scopus database. The results revealed that the paper of Brida and Risso (2009) is the most cited paper (74 citations).

Table 4 presents the top 10 authors and academic journals that cited the papers published in the EJTR. The findings showed that Stanislav Ivanov (33 citations), Craig Webster, (20 citations) and Andrea Giampiccoli (18 citations) have the biggest number of citations of articles published in the EJTR (20082020).

Besides, the EJTR's articles were highly cited in work appeared in the journals of 'Tourism Management' (73 citations), 'Sustainability' (67 citations), 'Current Issues in Tourism” (52) and 'Journal of Travel Research' (49 citations). 
Table 3. The 10 most cited articles in the EJTR (2008-2020)

\begin{tabular}{|c|c|c|c|}
\hline$\overline{\mathbf{R}}$ & Title & Author(s)/ Year & $\begin{array}{l}\text { Total } \\
\text { citations }\end{array}$ \\
\hline 1 & $\begin{array}{l}\text { Tourism as a factor of long-run economic growth: An } \\
\text { empirical analysis for Chile }\end{array}$ & (Brida \& Risso, 2009) & 74 \\
\hline 2 & $\begin{array}{l}\text { Dawning of the age of robots in hospitality and tourism: } \\
\text { Challenges for teaching and research }\end{array}$ & $\begin{array}{l}\text { (Murphy, Hofacker, \& } \\
\text { Gretzel, 2017) }\end{array}$ & 55 \\
\hline 3 & $\begin{array}{l}\text { The extent of use of basic Facebook user-generated } \\
\text { content by the national tourism organizations in Europe }\end{array}$ & $\begin{array}{l}\text { (Stankov, Lazic, \& } \\
\text { Dragicevic, 2010) }\end{array}$ & 55 \\
\hline 4 & $\begin{array}{l}\text { Tourism destination competitiveness: The French } \\
\text { regions case }\end{array}$ & $\begin{array}{l}\text { (Botti, Peypoch, Robinot, } \\
\text { \& Solonadrasana, 2009) }\end{array}$ & 45 \\
\hline 5 & $\begin{array}{l}\text { Residents' perceptions of tourism impact and their } \\
\text { support for tourism development: The case study of Cuc } \\
\text { Phuong national park, Ninh Binh province, Vietnam }\end{array}$ & (Pham \& Kayat, 2011) & 34 \\
\hline 6 & $\begin{array}{l}\text { Community-based and pro-poor tourism: Initial } \\
\text { assessment of their relation to community development }\end{array}$ & $\begin{array}{l}\text { (Saayman \& Giampiccoli, } \\
\text { 2016) }\end{array}$ & 29 \\
\hline 7 & $\begin{array}{l}\text { Dracula's image in tourism: Western bloggers versus } \\
\text { tour guides }\end{array}$ & (Banyai, 2010) & 24 \\
\hline 8 & $\begin{array}{l}\text { Cultural tourism and quality of life: Results of a } \\
\text { longitudinal study }\end{array}$ & $\begin{array}{l}\text { (Cecil, Fu, Wang, \& } \\
\text { Avgoustis, 2010) }\end{array}$ & 24 \\
\hline 9 & $\begin{array}{l}\text { Tourist loyalty toward shopping destination: The role of } \\
\text { shopping satisfaction and destination image }\end{array}$ & $\begin{array}{l}\text { (Suhartanto \& Triyuni, } \\
\text { 2016) }\end{array}$ & 23 \\
\hline 10 & $\begin{array}{l}\text { The way to Santiago beyond Santiago. Fisterra and the } \\
\text { pilgrimage's post-secular meaning }\end{array}$ & $\begin{array}{l}\text { (Blom, Nilsson, \& } \\
\text { Santos, 2016) }\end{array}$ & 22 \\
\hline
\end{tabular}

Table 4. Top 10 authors and journals that cited articles published in the EJTR (2008-2020)

\begin{tabular}{lllll}
\hline $\mathbf{R}$ & Authors & Journals & Citations \\
\cline { 2 - 5 } & Name & Citations & Title & 73 \\
\hline $\mathbf{1}$ & Ivanov Stanislav & 33 & Tourism Management & 67 \\
$\mathbf{2}$ & Webster Craig & $\mathbf{2 0}$ & Sustainability & 52 \\
$\mathbf{3}$ & Giampiccoli Andrea & $\mathbf{1 8}$ & Current Issues in Tourism & 49 \\
$\mathbf{4}$ & Suhartanto Dwi & 16 & Journal of Travel Research & 43 \\
$\mathbf{5}$ & Gretzel Ulrike & 10 & Tourism Economics & 43 \\
$\mathbf{6}$ & Mtapuri Oliver & 10 & Tourism Management Perspectives & 42 \\
$\mathbf{7}$ & Giacombo Del Chiappa & 9 & International Journal of Contemporary & 42 \\
& & & Hospitality Management & 41 \\
8 & Wise Nicholas A. & 9 & African Journal of Hospitality Tourism & 41 \\
& & & and Leisure & 39 \\
$\mathbf{9}$ & Bimonte Salvatore & 8 & Journal of Sustainable Tourism & 38 \\
$\mathbf{1 0}$ & Juan Gabriel Brida & 8 & Annals of Tourism Research & \\
\hline
\end{tabular}


Figure 4 presents the analysis of co-citation that visualises the cooperation between researchers and their co-citation.

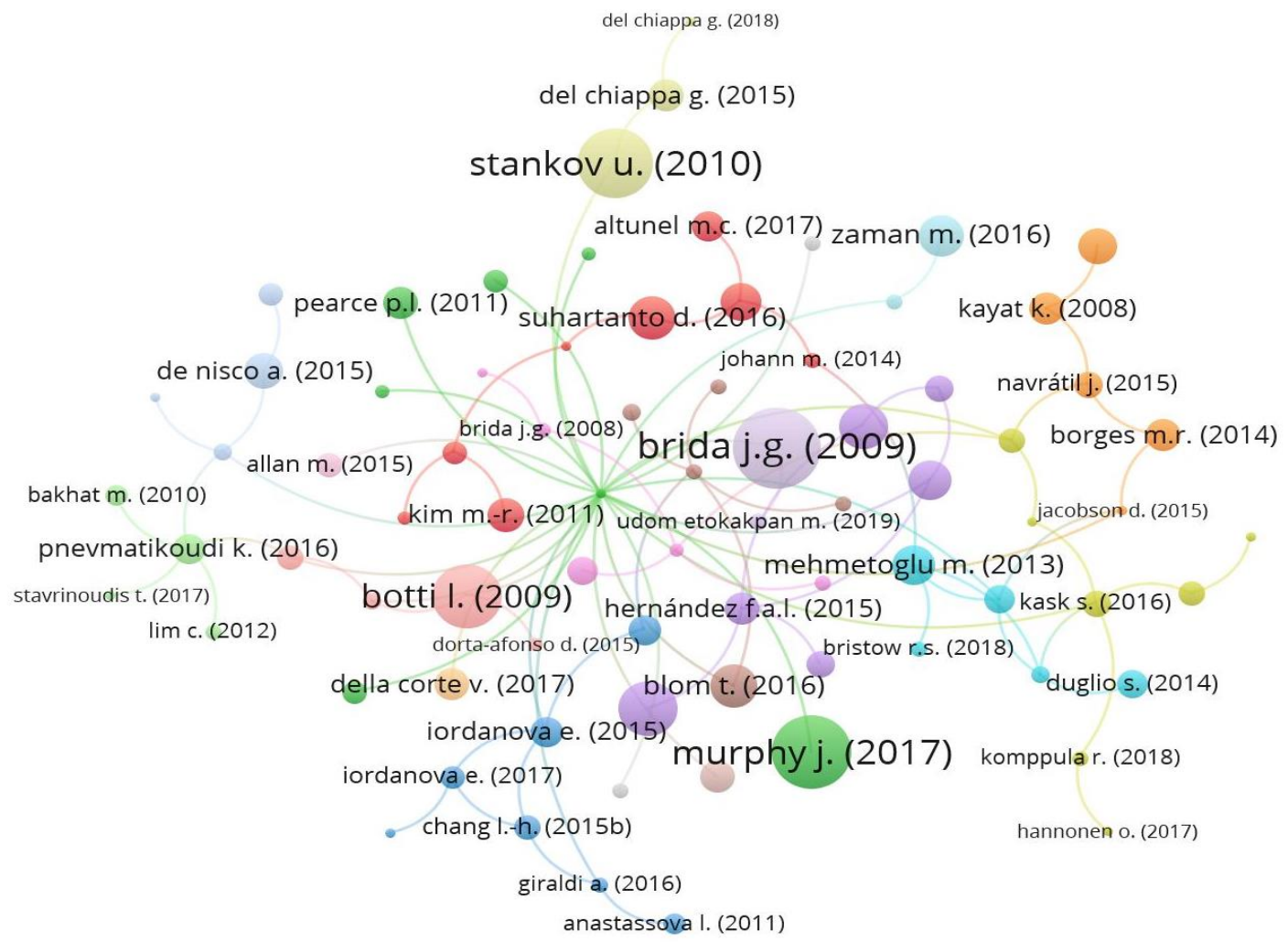

Figure 4. Finding of co-citation analysis by the published articles in the EJTR

The analysis of the co-citation of the authors' dependence on sources showed that the scholars mostly based the investigation on the high-ranked journals as follows as: 'Tourism Management' (Q1, h-index 179); 'Annals of Tourism Research' (Q1, h-index 158); 'International Journal of Hospitality' (Q1, h-index 179). In total, the authors cited 78 journals, which could be grouped into five clusters (Figure 5 ) as follows:

- Cluster 1 (red colour): contains 37 journals, the most cited is the 'International Journal of Hospitality Management', (186 citations from 77 sources).

- Cluster 2 (green colour): contains 22 journals, the most cited is the journal of 'Tourism Management' (1097 citations from 77 sources).

- Cluster 3 (navy-blue colour): contains 8 journals, the most cited is the 'Journal of Travel \& Tourism Marketing' (131 citations from 75 sources).

- Cluster 4 (yellow colour): contains 6 journals, the most cited is the 'Journal of Travel Research' (581 citations from 76 sources).

- $\quad$ Cluster 5 (purple colour): contains 5 journals, the most cited is the 'EJTR' ( 167 citations from 78 sources). 


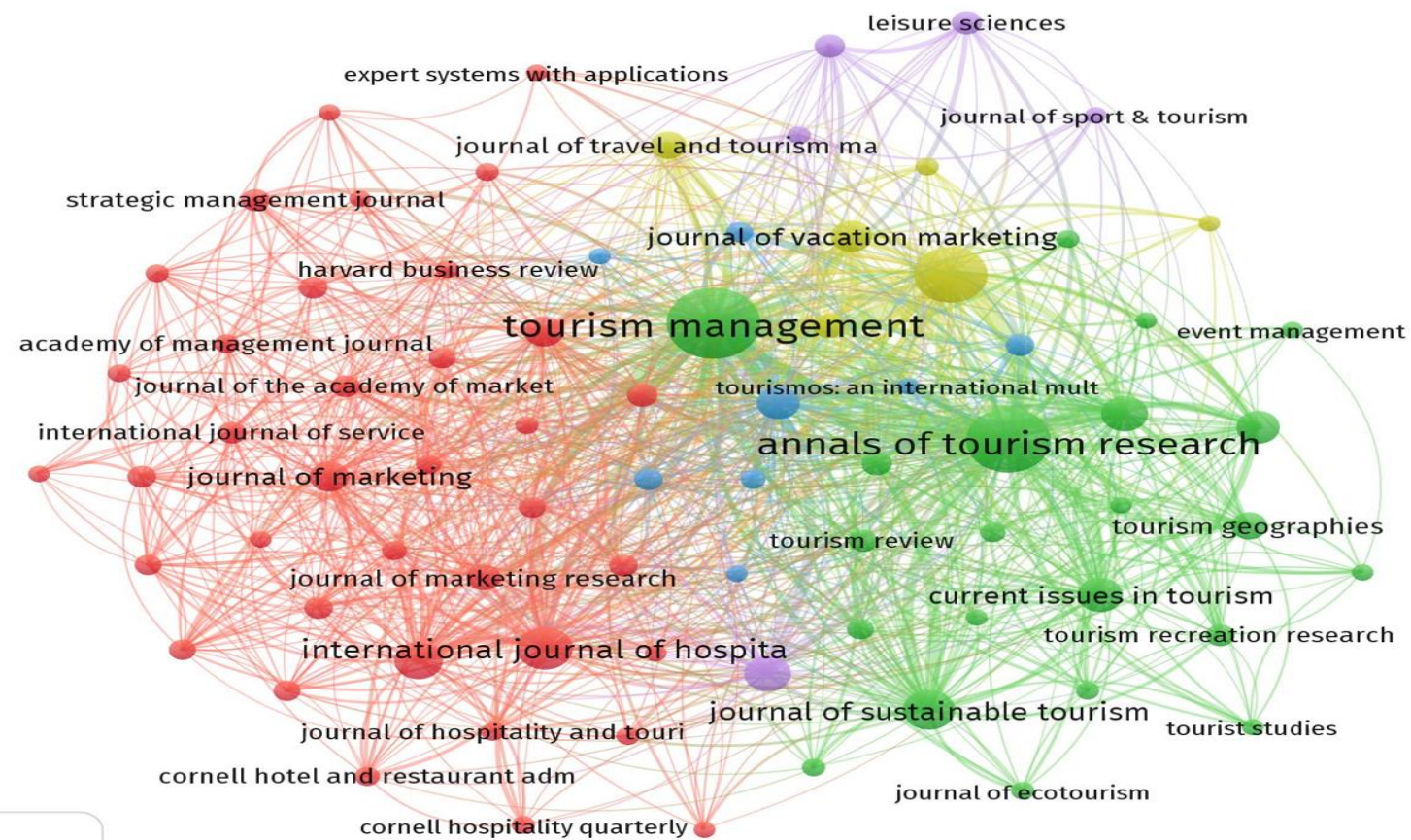

Figure 5. Finding of co-citation analysis dependent on the sources

\section{Co-occurrence analysis}

The findings of co-occurrence analysis allowed identifying the core scientific areas of peer-reviewed papers published in the EJTR between 2008 and 2020. Thus, using the data on links, total link strength and occurrence between keywords (Table 5), 7 clusters of scientific areas and themes were identified. Besides, the clusters were named considering the core keyword with the highest links, total link strength and occurrence.

The first biggest cluster (red) called as satisfaction and involved the keywords with the highest level of links. The links characterize the numbers of keywords which are used with analysed words. Thus, the keyword "satisfaction" meets in the analysed papers with the 7 words (destination; service quality; sustainability; food; rural tourism; tourist satisfaction; and destination image). The second cluster (green) relates with blue cluster through destination image (cluster 6) and navy blue (cluster 3) through destination management. The fourth cluster (yellow) could be cold as sustainability. This cluster contains 6 keywords from the paper, which focused on the analysis of tourism development in the framework of Sustainable development goals. The fifth cluster (purple) - rural tourism was an intermediator between red ( $1^{\text {st }}$ cluster) and navy-blue clusters ( $3^{\text {rd }}$ cluster). The seventh cluster (orange) contains 4 items and is located close to the yellow cluster. The finding of co-occurrence analysis is presented in Table 5 .

Using of VOSviewer allowed visualising the main scientific areas of the EJTR's papers: satisfaction; motivations; destination management; sustainability; rural tourism; destination image; tourism (Figure 6). The findings showed that publications on destination image and marketing, sustainable development began in 2014. The latest publication focused on the analysis of sustainable and rural tourism (Figure 7). 
Table 5. Findings of the co-occurrence analysis

Items of keywords -40

Links - 66

Number of clusters -7

Total links strength - 58

\begin{tabular}{|c|c|c|c|c|}
\hline Cluster & Keywords of the clusters & Links & Total links strength & Occurrences \\
\hline \multirow[t]{8}{*}{ Cluster 1} & Customer satisfaction & 4 & 3 & 4 \\
\hline & Destination & 4 & 3 & 3 \\
\hline & Experience & 3 & 3 & 3 \\
\hline & Hotels & 2 & 2 & 5 \\
\hline & Motivation & 2 & 2 & 4 \\
\hline & Satisfaction & 7 & 5 & 7 \\
\hline & Service quality & 5 & 2 & 3 \\
\hline & Social media & 2 & 2 & 3 \\
\hline \multirow[t]{7}{*}{ Cluster 2} & Airbnb & 2 & 1 & 3 \\
\hline & Behaviour & 1 & 1 & 3 \\
\hline & Motivations & 7 & 6 & 6 \\
\hline & $\begin{array}{l}\text { Socio-demographic } \\
\text { characteristics }\end{array}$ & 2 & 1 & 3 \\
\hline & Sport tourism & 2 & 3 & 4 \\
\hline & Travel behaviour & 3 & 3 & 4 \\
\hline & Volunteer tourism & 1 & 1 & 3 \\
\hline \multirow[t]{5}{*}{ Cluster 3} & Destination competitiveness & 1 & 1 & 3 \\
\hline & Destination governance & 3 & 3 & 3 \\
\hline & Destination management & 5 & 5 & 6 \\
\hline & Marketing & 2 & 1 & 3 \\
\hline & Tourist satisfaction & 3 & 2 & 5 \\
\hline \multirow[t]{6}{*}{ Cluster 4} & Food & 5 & 3 & 3 \\
\hline & Management & 3 & 2 & 3 \\
\hline & Social network analysis & 2 & 3 & 3 \\
\hline & Sustainability & 7 & 6 & 8 \\
\hline & Sustainable tourism & 3 & 2 & 10 \\
\hline & Tourism destination & 4 & 4 & 5 \\
\hline \multirow[t]{5}{*}{ Cluster 5} & Authenticity & 2 & 2 & 4 \\
\hline & Literature review & 4 & 3 & 3 \\
\hline & Rural tourism & 4 & 4 & 6 \\
\hline & Tourism development & 2 & 2 & 5 \\
\hline & Tourism research & 2 & 2 & 7 \\
\hline \multirow[t]{4}{*}{ Cluster 6} & Destination choice & 1 & 1 & 3 \\
\hline & Destination image & 9 & 8 & 14 \\
\hline & Destination marketing & 2 & 2 & 4 \\
\hline & Domestic tourism & 2 & 2 & 3 \\
\hline \multirow[t]{4}{*}{ Cluster 7} & Education & 3 & 3 & 3 \\
\hline & Leisure & 3 & 2 & 3 \\
\hline & Research & 3 & 3 & 3 \\
\hline & Tourism & 8 & 10 & 26 \\
\hline
\end{tabular}




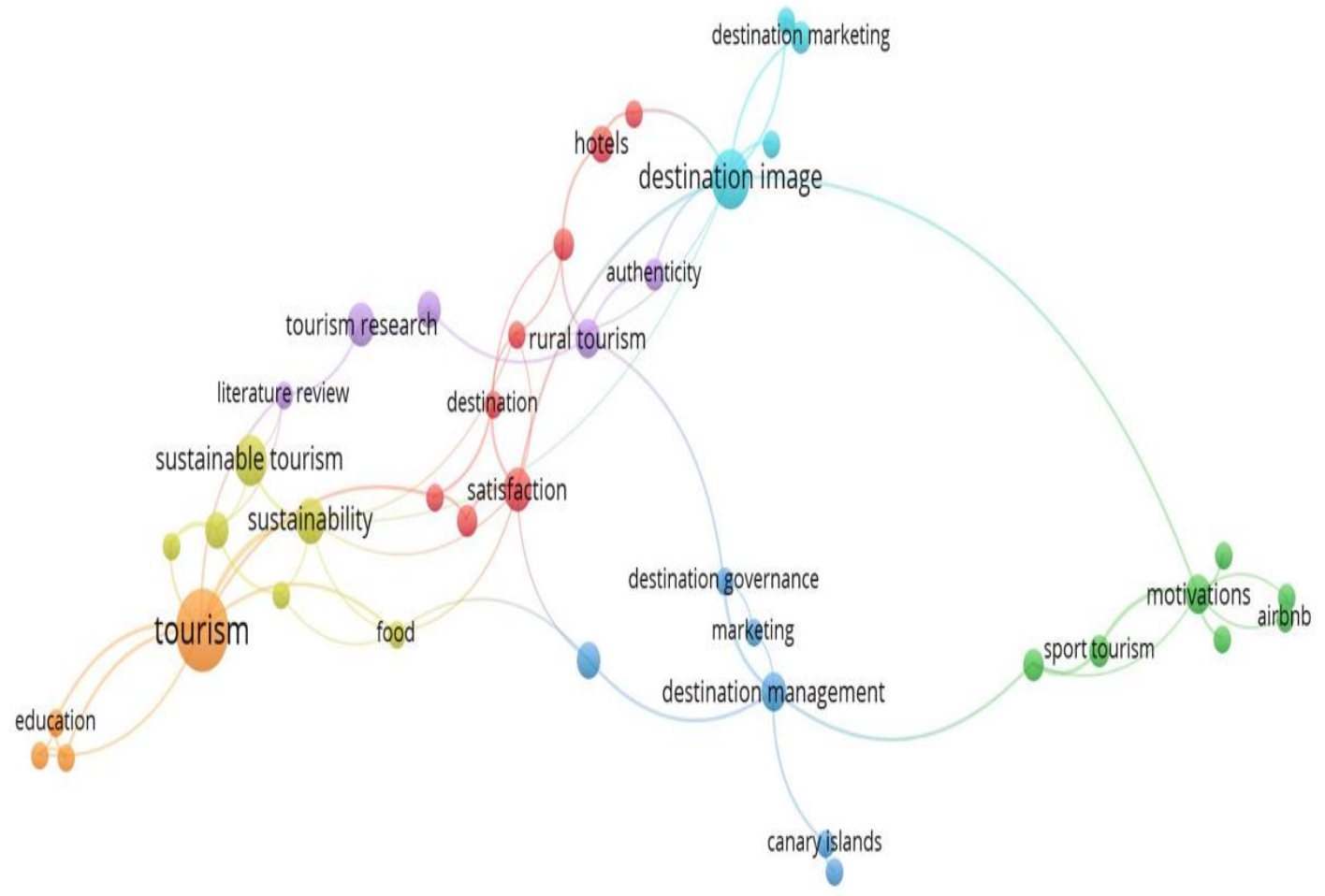

Figure 6. The visualising map of the results of the co-occurrence analysis

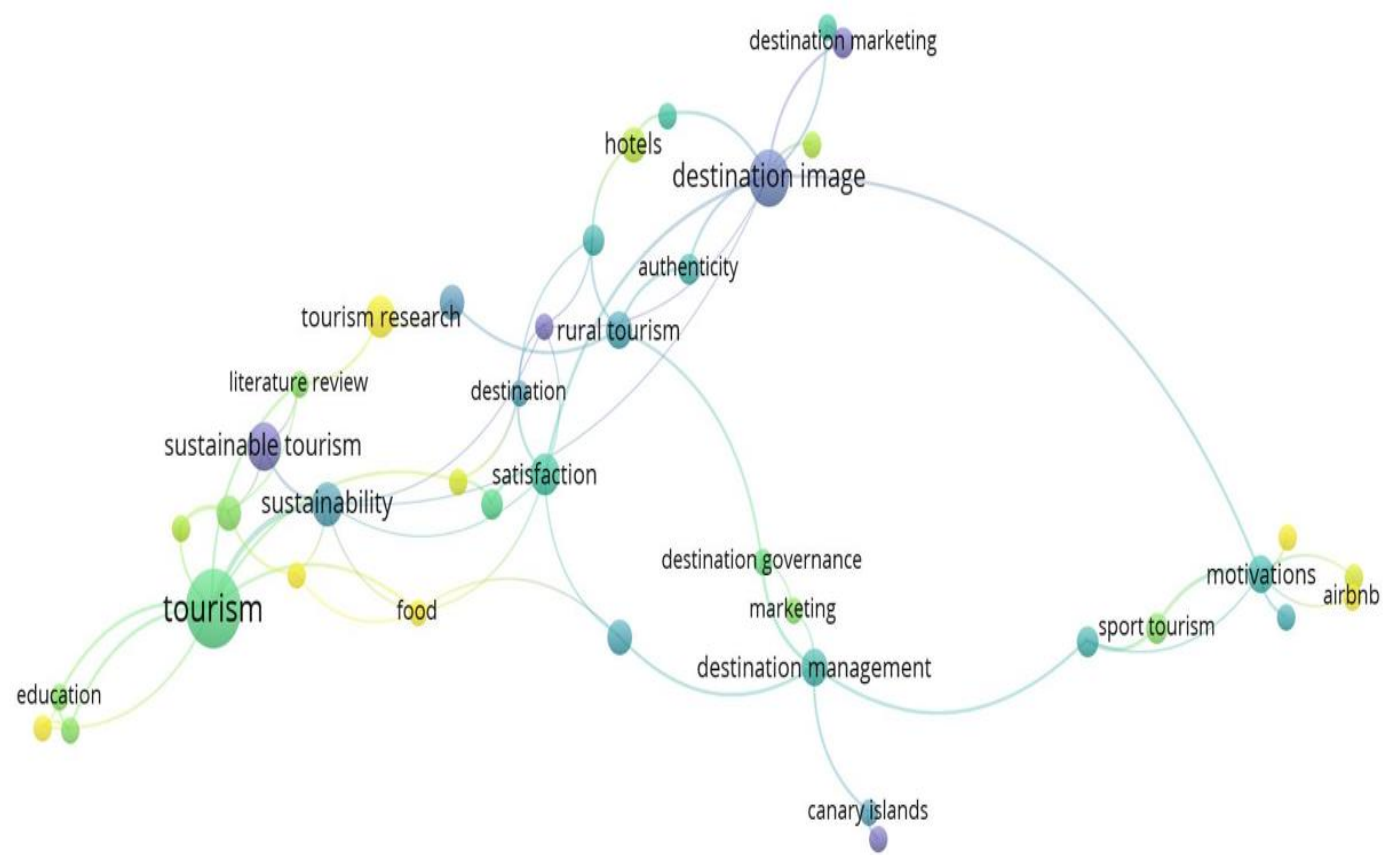

Figure 7. The visualising of co-occurrence analysis under the year of publication activation 


\section{Discussion and implications}

Tourism is one of the world's biggest industries considering its revenue and contributions to GDP worldwide. Tourism is seen as a significant industry including a range of economic, social, cultural and environmental aspects of development in many countries around the world (Soliman, 2015, 2019). With the increasing importance of tourism, there is a significant growth in the number of publications and academic journals within the tourism, leisure and hospitality context. To this end, analysing, visualisation and evaluation of the scientific productions of tourism and hospitality journals are crucial due to the substantial and integrative role of tourism in spurring growth across multiple services industries and sectors worldwide. In this regard, the current paper aimed to analyse and visually map the scientific productions (peer-reviewed articles) of the EJTR, as one of the leading journals in the Eastern Europe region in general and in Bulgaria in particular. In doing so, the present study conducted a blended of bibliometric methods, including evaluative and relational metrics using Excel and VOSviewer software to analyse the main trends, evolution, themes, and direction related to the papers published in the EJTR over a period of 12 years, from 2008 to 2020.

The findings of bibliometric analysis of the papers published in the EJTR confirmed the increasing tendency of the investigation in tourism issues. The results of the analysis of publication activities showed that the number of articles in the EJTR has been remarkably increasing over the given period. Starting with 7 papers in 2008, the number of published articles in the EJTR reached 36 papers by the end of September 2020. Based on our following up the journal's websites in social networks, this number will surely increase by the end of 2020. Besides, the rating of the EJTR according to CiteScore and SJR has been increasing since 2008 within the two categories of 'Geography, Planning and Development' and 'Tourism, Leisure and Hospitality Management'. The tendency of rating growth was confirmed by the increase of the citation's figures during the selected period. This could be ensured by the work of Brida and Risso (2009) that has 74 citations and two papers (Murphy et al., 2017; Stankov et al., 2010) which have 55 citations for each one.

In addition, the peer-reviewed articles published in the EJTR were cited by the leading and high-ranked academic journals within the tourism and hospitality domain (e.g., Tourism Management, Annals of Tourism Research, Current Issues in Tourism, Journal of Travel Research, Tourism Management Perspectives, International Journal of Contemporary Hospitality Management, and Journal of Sustainable Tourism). This reflects the high quality of the scientific work produced by the EJTR.

Moreover, the co-occurrence analysis allowed concluding that all published papers focused on the investigations of the issues in tourism, which could be divided by 7 clusters. Each cluster had the core term which had the highest links, total links strength and co-occurrences: cluster 1 - satisfaction; cluster 2 - motivations; cluster 3 - destination management; cluster 4 - sustainable tourism; cluster 5 - rural tourism; cluster 6 - destination image; cluster 7 - tourism. The retrospective analyses of the publications in EJTR showed that, in 2014, the issues on destination image and rural tourism were the first scientific direction, which were investigated by scholars in the framework of tourism development. The latest publications focused on the analyses of rural and food tourism, travelling online platforms (booking, Airbnb, etc.).

The current study presents some theoretical implications through the analysis and visualisation of the EJTR's scientific output. In this regard, it is evident that there are several bibliometric studies that were conducted to analyse a specific area or subject within the tourism and hospitality context, including bibliometric analysis performed to visualise and map the productions of tourism and hospitality journals. However, there is no prior study that has conducted a comprehensive bibliometric approach 
to analyse the EJTR's scientific work. In addition, using different methodological approaches offers several insights about the literature evolution concerning the EJTR. Thus, the structure initially addressed different techniques to present solid bibliometric analysis. To this end, the bibliometric analysis presented in this research fulfilled the necessary criteria for the identified results, as well as clarifying the understanding of the key themes and directions of the EJTR's production over the last years. Additionally, the different analyses used in this study evidently present an adequate impetus for the EJTR in a different database like WoS and/or Scopus indexed journals. Another theoretical contribution can be observed in the journal ranking, which is crucial for some scholars, as they are requested to publish in journals indexed in global databases. Moreover, the results of this paper contribute to the existing knowledge of bibliometric studies in the tourism and hospitality setting by analysing the trends and evolution of the big data related to the EJTR. Indeed, the results contribute to the literature of tourism by presenting general overviews of the scientific work produced by the EJTR applying different metrics of bibliometric analysis. Furthermore, the theoretical contributions can support the practical development to get more results and outlines regarding a scientific work presented by an academic journal (e.g., the EJTR).

Moreover, this paper has several practical contributions. To begin with, bibliometric studies provide valuable information to scholars to increase their knowledge about big data connected to a certain topic, domain or journal. They also ensure a meaningful experience to them regarding the performance of scholars, institutions, and academic journals. In addition, bibliometric tourism-related studies at its best provide explicit direction for the management of tourism businesses, tourism higher education institutions, and research centres about precise and clear indicators of the performance of authors, institutions, journals, countries, etc. In addition, this research adopts different approaches of bibliometric analysis to analyse and map the production of the EJTR, therefore, this paper provides clear guidelines for researchers who plan to conduct bibliometric studies of the scientific output of academic journals in different contexts, involving the tourism and hospitality field. Moreover, the findings of this paper present rigorous indicators connected to the EJTR's output, thus, scholars could maintain and develop their research directions, by using different methods, to achieve their goals based on the EJTR's published papers. Another option is to analyse the performance of specific countries, as identified in Portugal and Spain in terms of their performance concerning the EJTR's studies. Moreover, the cocitation network analysis can enable tourism and hospitality researchers to identify the keywords and the changes in research themes over time. The co-citation analysis is a helpful tool for the identification of thematic evolution and methodology focus that is an antecedent for further investigations in a certain field.

\section{Limitations and future research}

Like any research, there are some limitations that should be considered for future research. First, the current paper analysed and mapped the article published in the EJTR using a set of bibliometric methods, including evaluative metrics (productivity and impact metrics) and relational methods (cocitation analysis, co-authorship analysis, and co-occurrence analysis). Therefore, future studies are recommended to employ traditional review techniques (e.g., systematic literature reviews, structured literature reviews, and/or meta-analyses/reviews). In addition, other rational bibliometric metrics (e.g., bibliographic coupling/analysis) to provide solid insights into the scientific productions of the EJTR. Second, this paper focused on peer-reviewed articles published in the EJTR. As a result, future research can focus on other publications of the EJTR, such as research notes, book reviews, and editorial. This can help in presenting a clearer overview of the main trends, directions, and performance of the EJTR. Third, this present study applied VOSviewer software to analyse and map the collected and retrieved data. Thus, future studies can employ other common software programs (e.g., R package, BibExcel, 
CiteSpace, etc.) used to visualise the big data in different contexts. Finally, future research can conduct a bibliometric study on the scientific production of other journals within the tourism, leisure and hospitality context according to a specific region (e.g., Europe or East Asia, etc.) or based on certain criteria such as ranking, database, the journal's nature and scope, the publisher, etc.

\section{References}

Banyai, M. (2010). Dracula's image in tourism: Western bloggers versus tour guides. European Journal of Tourism Research, 3(1), 5-22.

Benckendorff, P., \& Shu, M. L. (2019). Research impact benchmarks for tourism, hospitality and events scholars in Australia and New Zealand. Journal of Hospitality and Tourism Management, 38, 184190.

Benckendorff, P., \& Zehrer, A. (2013). A network analysis of tourism research. Annals of Tourism Research, 43, 121-149.

Blom, T., Nilsson, M., \& Santos, X. (2016). The way to Santiago beyond Santiago. Fisterra and the pilgrimage's post-secular meaning. European Journal of Tourism Research, 12, 133-146.

Botti, L., Peypoch, N., Robinot, E., \& Solonadrasana, B. (2009). Tourism destination competitiveness: the French regions case. European Journal of Tourism Research, 2(1), 5.

Brida, J. G., \& Risso, W. A. (2009). Tourism as a factor of long-run economic growth: An empirical analysis for Chile. European Journal of Tourism Research, 2(2), 178-185.

Butler, R. (2015). The evolution of tourism and tourism research. Tourism Recreation Research, 40(1), 16-27.

Cecil, A. K., Fu, Y.-Y., Wang, S., \& Avgoustis, S. (2010). Cultural tourism and quality of life: Results of a longitudinal study. European Journal of Tourism Research, 3(1), 54-66.

Chang, C. L., \& McAleer, M. (2012). Citations and impact of ISI tourism and hospitality journals. Tourism Management Perspectives, 1, 2-8.

Cunill, O. M., Salvá, A. S., Gonzalez, L. O., \& Mulet-Forteza, C. (2019). Thirty-fifth anniversary of the International Journal of Hospitality Management: A bibliometric overview. International Journal of Hospitality Management, 78, 89-101.

del Río-Rama, M. d. 1. C., Maldonado-Erazo, C. P., \& Álvarez-García, J. (2018). State of the art of research in the sector of thermalism, thalassotherapy and spa: A bibliometric analysis. European Journal of Tourism Research, 19, 56-70.

del Río-Rama, M. d. l. C., Maldonado-Erazo, C., Durán-Sánchez, A., \& Álvarez-García, J. (2019). Mountain tourism research. A review. European Journal of Tourism Research, 22, 130-150.

Evren, S., \& Kozak, N. (2014). Bibliometric analysis of tourism and hospitality related articles published in Turkey. Anatolia, 25(1), 61-80.

Fahimnia, B., Sarkis, J., \& Davarzani, H. (2015). Green supply chain management: A review and bibliometric analysis. International Journal of Production Economics, 162, 101-114.

Guo, F., Li, F., Lv, W., Liu, L., \& Duffy, V. G. (2020). Bibliometric Analysis of Affective Computing Researches during 1999 2018. International Journal of Human-Computer Interaction, 36(9), 801814 .

Hall, C. M. (2011). Publish and perish? Bibliometric analysis, journal ranking and the assessment of research quality in tourism. Tourism Management Perspectives, 32, 16-27.

Ivanov, S. (2018). The European Journal of Tourism Research: A Personal Journey. European Journal of Tourism Research, 18, 5-12.

Koseoglu, M. A., Law, R., \& Dogan, I. C. (2018). Exploring the social structure of strategic management research with a hospitality industry focus. International Journal of Contemporary Hospitality Management, 32 (2), 463-488. 
Köseoglu, M. A., Law, R., Okumus, F., Barca, M., \& Dogan, I. C. (2019). Evolution of strategic management research lines in hospitality and tourism. Journal of Hospitality Marketing $\mathcal{E}$ Management, 28(6), 690-710.

Koseoglu, M. A., Rahimi, R., Okumus, F., \& Liu, J. (2016). Bibliometric studies in tourism. Annals of Tourism Research, 61, 180-198.

Kumar, S., Sureka, R., \& Vashishtha, A. (2020). The Journal of Heritage Tourism: a bibliometric overview since its inception. Journal of Heritage Tourism, 15(4), 365-380.

Leung, X. Y., Sun, J., \& Bai, B. (2017). Bibliometrics of social media research: A co-citation and co-word analysis. International Journal of Hospitality Management, 66, 35-45.

Marsh, S. E. (2020). Making Connections and Measuring Performance: Bibliometric Analysis of MultiAttribute, Preference-Based Health-Related Quality of Life Research in South Africa. Value in Health Regional Issues, 22, 99-107.

Mas-Tur, A., Kraus, S., Brandtner, M., Ewert, R., \& Kürsten, W. (2020). Advances in management research: a bibliometric overview of the Review of Managerial Science. Review of Managerial Science, 14(5), 933-958.

Mauleon-Mendez, E., Genovart-Balaguer, J., Merigo, J. M., \& Mulet-Forteza, C. (2018). Sustainable tourism research towards twenty-five years of the Journal of Sustainable Tourism. Advances in Hospitality and Tourism Research, 6(1), 23-46.

McKercher, B. (2012). Influence ratio: An alternate means to assess the relative influence of hospitality and tourism journals on research. International Journal of Hospitality Management, 31(3), 962-971.

Merigó, J. M., Mulet-Forteza, C., Martorell, O., \& Merigó-Lindahl, C. (2020). Scientific research in the tourism, leisure and hospitality field: a bibliometric analysis. Anatolia, 1-15.

Mokhtari, H., Soltani-Nejad, N., Mirezati, S. Z., \& Saberi, M. K. (2020). A bibliometric and altmetric analysis of Anatolia: 1997-2018. Anatolia, 1-17.

Moreno-Gil, S., Parra-López, E., Picazo-Peral, P., \& Díaz-Domínguez, C. (2020). The dissemination of tourism scientific research in Latin American journals. A bibliometric study. Anatolia, 31(4), 549564.

Mulet-Forteza, C., Genovart-Balaguer, J., Mauleon-Mendez, E., \& Merigó, J. M. (2019). A bibliometric research in the tourism, leisure and hospitality fields. Journal of Business Research, 101, 819-827.

Mulet-Forteza, C., Genovart-Balaguer, J., Merigó, J. M., \& Mauleon-Mendez, E. (2019). Bibliometric structure of IJCHM in its 30 years. International Journal of Contemporary Hospitality Management, 31(12), 4574-4604.

Mulet-Forteza, C., Martorell-Cunill, O., Merigó, J. M., Genovart-Balaguer, J., \& Mauleon-Mendez, E. (2018). Twenty-five years of the Journal of Travel \& Tourism Marketing: a bibliometric ranking. Journal of Travel \& Tourism Marketing, 35(9), 1201-1221.

Murphy, J., Hofacker, C., \& Gretzel, U. (2017). Dawning of the age of robots in hospitality and tourism: Challenges for teaching and research. European Journal of Tourism Research, 15(2017), 104-111.

Padrón-Ávila, H., \& Hernández-Martín, R. (2020). How can researchers track tourists? A bibliometric content analysis of tourist tracking techniques. European Journal of Tourism Research, 26, 2601

Pham, L., \& Kayat, K. (2011). Residents' perceptions of tourism impact and their support for tourism development: The case study of Cuc Phuong National Park, Ninh Binh province, Vietnam. European Journal of Tourism Research, 4(2), 123-146.

Pritchard, A. (1969). Statistical bibliography or bibliometrics. Journal of documentation, 25(4), 348-349.

Saayman, M., \& Giampiccoli, A. (2016). Community-based and pro-poor tourism: Initial assessment of their relation to community development. European Journal of Tourism Research, 12, 145-190.

Scopus database. (2020). Sources. Retrieved 20-11, 2020, from https://www.scopus.com/sources.uri 
Shen, Y., Morrison, A. M., Wu, B., Park, J., Li, C., \& Li, M. (2018). Where in the world? A geographic analysis of a decade of research in tourism, hospitality, and leisure journals. Journal of Hospitality E Tourism Research, 42(2), 171-200.

Shvindina, H. (2019). Coopetition as an emerging trend in research: perspectives for safety \& security. Safety, 5(3), 61.

SJR. (2020). Scimago Journal \& Country Rank. Retrieved 10-11, 2020, from https://www.scimagojr.com/journalrank.php

Soliman, M. (2015). Pro-poor tourism in protected areas-opportunities and challenges: The case of Fayoum, Egypt". Anatolia, 26(1), 61-72.

Soliman, M. (2019). Extending the Theory of Planned Behavior to Predict Tourism Destination Revisit Intention. International Journal of Hospitality $\mathcal{E}$ Tourism Administration, 1-26.

Stankov, U., Lazic, L., \& Dragicevic, V. (2010). The extent of use of basic Facebook user-generated content by the national tourism organizations in Europe. European Journal of Tourism Research, 3(2), 105-113.

Suhartanto, D., \& Triyuni, N. N. (2016). Tourist loyalty toward shopping destination: the role of shopping satisfaction and destination image. European Journal of Tourism Research, 13, 84-102.

The EJTR Website. (2020). The European Journal of Tourism Research. Retrieved 10-10, 2020, from https://ejtr.vumk.eu/index.php/about

Tomaszewski, R. (2019). Substance-based bibliometrics: identifying research gaps by counting and analyzing substances. ACS omega, 4(1), 86-94.

Tregua, M., D'Auria, A., \& Costin, H. (2020). \#10yearschallenge: how co-creation permeated tourism research. A bibliometric analysis. European Journal of Tourism Research, 24, 2409.

Van Eck, N., \& Waltman, L. (2018). VOSviewer manual [PDF file]. Leiden. The Netherlands. University of Leiden.

Zopiatis, A., Theocharous, A. L., \& Constanti, P. (2015). The past is prologue to the future: an introspective view of hospitality and tourism research. Scientometrics, 102(2), 1731-1753.

Received: $22 / 11 / 2020$

Accepted: 07/12/2020

Coordinating editor: Stanislav Ivanov 